\title{
1 Why bank funding?
}

As noted in the Preface, a bank is a financial institution that holds insured customer deposits, borrows other resources to leverage the equity investment of its owners, and then uses the resulting resources to make loans and to acquire other financial assets. Except when needed to distinguish depository banks from other kinds of financial institutions, I will not add 'depository' or 'credit' to the term bank. Deposits are the inputs for the bank's defining process: intermediation. In this process, the bank borrows funds for a short term and recirculates them into the financial system through loans and other investments, most of which have a longer term. Take the simplest case: a bank provides a borrower with a 30-year mortgage using funds acquired through demand deposits. The bank has transformed very short-term funds into an asset (the mortgage) that has a much longer term. The transformation of maturity - from a short-dated financial item to a long-dated one - is one aspect of intermediation, but the bank is converting other financial attributes too.

This chapter addresses three key questions raised by bank intermediation. First, why does the state regulate bank funding with such a heavy hand? As argued below, the state has many compelling interests in a stable banking sector, which serves both public and private needs for credit. Except for public utilities, banks may be the single most regulated industry in the United States. In particular, federal regulation imposes prudential regulation that mandates minimum capital requirements for banks to promote their ability to absorb losses without shutting down. The federal government also stands ready to provide back-up funding for banks when market lenders refuse to do so.

Given the expanding universe of financial intermediaries, however, why draw a circle around the depository banking model and shower it with both burdensome regulation and government largesse? Making this second question more compelling, non-bank firms provide credit and payments services and, increasingly, hold a larger share of financial assets, making the traditional bank seem like a relic of intermediation. Nevertheless, as argued below, the depository bank model remains a touchstone for analyzing the financial sector and regulating it, even as it is populated with new entities and products. 
Third, given the bank's intended function as a lender why focus on the bank's own funding? Funding matters to most private and public firms, but in large part for banks the funding model is their business model. The bank needs funds to make a loan, buy a security, honor a depositor's check, or pay a creditor. In addition to deposits, banks borrow at terms ranging from one day to a year: banks borrow at longer terms by issuing debt or getting loans from other institutions. Endowed with special funding advantages, banks profit by borrowing cheaply and charging more on their loans and investments, capturing a spread known as net interest margin. However, these funding hydraulics leave banks vulnerable to a variety of financial risks.

Answering these questions provides the foundation for the book's argument and introduces its major themes: the bank's intrinsic illiquidity, from which profits derive; the special challenges of the bank's short-term financial position; the role of funding practices in precipitating and then resolving the 2007 financial crisis; and the challenges of regulating funding. These themes provide the reader with a framework for understanding not only banks but all financial intermediaries.

\section{A. WHY THE FEDERAL GOVERNMENT IMPOSES PRUDENTIAL REQUIREMENTS}

As imagined by Alexander Hamilton, the project of a federal government included a national banking institution. However, attempts to create a permanent national bank through the First and Second Bank of the United States did not succeed, in part because of the industrial balance of powers at the time. Agricultural interests viewed an official national bank with suspicion. It would take the financing needs of the Civil War to overcome some of this resistance. To establish a national currency, Abraham Lincoln and Congress created the national banking system and Office of the Controller of the Currency. Apart from credit that it might make available to customers - the system helped to consolidate a national currency, so serving an important public interest.

The next major structural change came half a century later, when Congress established the Federal Reserve System. Its stated goal was to serve as a mechanism for making the money supply more elastic to meet the changing credit needs of business conditions. The notion of financial stability would not emerge as such for another century, because the notion of a financial sector would take a while to develop. Currency elasticity, however, was an early proxy for financial stability, a public interest which would come into its own only after the financial crisis of 2007-2008. 
The extensive bank reforms of the New Deal contributed to this project by spinning off riskier financial activities in non-bank entities like the dealer bank and putting in place deposit insurance. It was during this period that the federal government began to insure retail deposits and expand prudential oversight of depository institutions to promote their stability.

Prudential regulation of bank funding by the federal government might seem redundant given that banks must adhere to state laws about minimum capital requirements for corporations and other business entities. Through the 19th and into the middle of the 20th century, state law established minimum capital requirements for corporations using parvalue stock and some common law creditor-protection doctrines. ${ }^{1}$ Since then, the modern trend has been away from meaningful capital regulation and towards giving managers discretion to restate the corporation's capital requirements. So, lenders have the onus to bargain for covenants that will encourage the bank to keep adequate capital.

As a result, these lenders impose open market capital standards on the bank's funding in addition to any requirements of state law. Corporate borrowers - including banks - must contend with these funding requirements, put in place through contractual provisions in loan agreements or indenture agreements used when borrowing through securities. As a condition of credit, for example, the bank may have to assume limits about its leverage ratio, short-term borrowing, dividend policy, or its liquidity. In effect, private law subsumes disputes about the bank's funding into the shareholder-bondholder conflict, that is, a more general opposition of interests between risk-friendly owners and risk-averse creditors. ${ }^{2}$

1 Depending on the state of its incorporation and its line of business, a firm must comply with legal requirements about adequate capitalization. State sources of law include enabling statutes, the issuer's charter or certificate of incorporation, and by-laws. If it issues securities, it may also have to follow disclosure requirements about diverse aspects of its operations, including financial structure. If it is listed on an exchange, it may also have to comply with the exchange's listing standards. The classic text on the state law of capital structure remains Legal Capital. Bayless Manning and James J. Hanks, Jr., Legal Capital 3rd edn (Foundation Press, 1990). Older state law standards that imposed objective minimum capital standards based on par-value and stated capital have given way to statutes giving the board discretion to set capital reserves by fiat. By making the definition of surplus more elastic, these legal capital standards give boards and managers more discretion to upstream value to shareholders through dividends or share repurchases. Once equity became the purview of an administrative decision (typically subject to the business judgment rule's presumption of validity) it no longer serves as a liquidated amount of reserves. Hence the common law notion that equity served as a trust fund for the benefit of creditors may no longer make sense.

2 The owner-creditor dichotomy structures corporate governance by granting 
In the opinion of the federal government, these state law and contractual mechanisms do not go far enough in promoting the bank's funding stability. When its creditors hold the upper hand, they may keep the bank stable through contract. However, when private covenants in loan agreements and bonds fail to mitigate the bank's intrinsic proneness to instability, the bank's funding structure may become unstable. Therefore, federal law supplements private law mechanisms with a battery of prudential requirements to promote the bank's stability and, especially after the crisis, its funding too.

Federal law does so in the name of the public interest for at least four major reasons. First, the banking system has become a foundational sector of modern economies. Banks pay a key role in the payments system by holding transaction accounts and facilitating settlement of obligations. Moreover, credit has become a staple commodity, like energy. Consumers use it to pace their consumption by borrowing for major purchases like education, a home, and other durables. Businesses use credit to amplify the capital resources of their owners. However, credit is a complex commodity: it is a financial intangible permanently vulnerable to changes in expectations about the future. This vulnerability makes credit markets volatile, an outcome that the state wants to manage. Not surprisingly, the history of banking regulation is a history of crisis.

Second, as part of its social contract with the banking sector the federal government remains financially exposed to failing banks because deposit insurance leaves the public fisc on the hook for bank failures. Banks pay risk-based assessments for deposit insurance, but the public fisc remains as the back-stop to deposits because Congress appropriates public resources to the Federal Deposit Insurance Corporation when these assessments are insufficient to cover the costs of resolving failed banks. Making matters worse, banks are born illiquid and remain so by design because of their activities as intermediaries. Providing long-term credit to other borrowers condemns the bank to a financial mismatch that firms in other industries would avoid. Hence, deposit insurance exposes the federal government to significant risk in its role as guarantor. In addition to protecting the public

owners fiduciary duties and relegating creditors primarily to contract law. Common law doctrines such as fraudulent conveyance and veil-piercing also protect creditors - as does the disputed view that creditors may enjoy fiduciarystyle rights in the zone of insolvency - but contract remains the primary tool for creditors. Similar seniority conflicts can also arise within equity investors, for example conflicts between preferred shareholders and common shareholders. 
from interruptions in banking services, prudential regulation limits the federal government's exposure to failing banks. ${ }^{3}$

Third, the government uses a private banking system to further a variety of policies. Central banks depend on banks to implement. Governments also use the banking system to further political priorities, early examples being farm credit and home loan programs. In effect, the government maintains a parallel credit market with important links to private banks. Analogously, in the transportation market, this would be like the federal government operating its own railway switching station.

Finally, the state has recurring financing needs which leave it highly interested in the stability of the credit market. The market interest rates determined here will influence the government's own borrowing costs. Banks act as market makers for public debt because - in part due to federal restrictions about the investments that they can own - banks hold substantial portfolios of the federal government's debt. Doing so creates investment demand for this debt, makes it more liquid, and reduces the government's borrowing costs. The government rewards the banking sector by keeping some of its cash reserves - for example from tax receipts - in private banks.

So, for all of these reasons - to stabilize credit, to promote a stable payments system, to facilitate monetary policy, to limit financial risk, and to meet its own needs as a borrower - the state wants banks to adopt stable funding structures. The United States Constitution provides legal authority to promote these interests through several provisions, including the power to regulate commerce, to coin money, to punish counterfeiters, and to borrow, as well as any incidental powers necessary to these enumerated ones. ${ }^{4}$ Relying on these authorities, the federal government has nudged, promoted, and pruned the banking sector into a sprawling network that vindicates Alexander Hamilton's early vision of the financial sector.

3 Though these rules bind private banks, they do not bind regulators or the authorities from coming to the defense of banks facing liquidity troubles. Faced with a situation in which a bank - or the banking sector as a whole-faces financial pressure, the authorities may dispense with loss-absorbing features of this capital regime and mutualize private losses.

4 The first major federal banking case rested on whether the federal government had the authority to charter a bank. See McCulloch v. Maryland, 17 U.S. 316 (1819). It did. See $i d$. 


\section{B. BANKNESS}

One of the ongoing challenges in banking regulation is determining the legal perimeter of a bank. The contemporary phase of that issue starts with the New Deal, particularly its provisions regarding federally-insured deposits. To limit the federal government's financial exposure, depository banking was confined to commercial banks and segregated from riskier financial activities that then banks had previously conducted. These commercial banks could accept federally-insured deposits but could not invest in speculative ventures. ${ }^{5}$ Instead, commercial banks were allowed to invest in a small universe of securities, including government securities and high-quality fixed-income securities. ${ }^{6}$ Forbidden from accepting insured deposits, dealer banks registered as broker-dealers with the U.S. Securities and Exchange Commission and participated as both agent and principal in a wider range of speculative enterprises.

Since then, federal law has subjected depository banks to a unique legal regime that includes extensive regulation of the business model as well as unrivaled access to government financial support not available to any other type of financial intermediary. In 1982, Federal Reserve official Gerald Corrigan asked what made banks special enough to deserve this status. He suggested that three factors other than maturity intermediation made depository banks functionally distinctive within the financial sector that merited special regulation: banks offered transaction accounts; provided back-up liquidity for other institutions; and served as the 'transmission belt' for monetary policy. ${ }^{7}$ Transaction accounts relate to the bank's role in the payments mechanism. Providing back-up liquidity reflects

5 The origins of the depository bank model can be traced to institutions that developed to facilitate trade and settlement. These institutions accepted gold and other assets on deposit for safekeeping. Banks also came to assume the function of providing retail and business clients with liquidity. They rediscounted commercial promissory obligations and, in general, became associated with the shift from commodity to paper currencies. The bank also developed the transactional checking account that let clients settle payments to other actors. In the United States, the establishment of the Federal Reserve in 1913 validated this business model and helped to make it a permanent part of the financial system. In time, these depository banks became associated with the reserve mechanism, which served both private ends and public interests such as monetary policy.

6 Indeed, the notion of what came to be considered 'investment-grade' securities referred to the kinds of securities in which national banks were allowed to invest. To a limited extent, commercial banks acted as market-markers for these asset classes insofar as they provided demand for them, although not to the extent that, say, the Department of the Treasury's primary dealers provide for new issues of public debt.

7 E. Gerald Corrigan, Are Banks Special?, Fed. Res. Bank of Minneapolis 
the bank's role not in maturity intermediation, but, instead, in helping customers manage the funding demands of contingencies. The third factor reflects the bank's role as an interface between the credit market as a whole and the central bank, which uses its transactions with private banks to influence the direction of interest rates.

Does this still make banks special? One could plausibly conclude 'no'. Many non-bank firms provide payments services through transaction accounts and a variety of non-bank firms and mechanisms provide back-up liquidity (including to banks). Indeed, today non-bank firms play such an important role in originating and trading credit that they have created a shadow banking sector that operates parallel to the regulated banking sector and provides bank-style financial services. This sector includes investment banks, hedge funds, insurers, special-purpose vehicles, asset managers and money market funds. ${ }^{9}$ Though these intermediaries originate and trade credit in a similar way to banks, federal regulation does not treat these firms as banks, hence the analogy to a shadow. During the past few decades, the share of financial assets held by a bank has shrunk. At one point, as much as 70 per cent of financial assets were held in banks, but today perhaps 30 per cent remains because other types of financial intermediaries have siphoned funds out of banks. At the same time, the seepage of U.S. dollars into Euromarkets beyond the effective reach of the Fed's decision-making power has reduced the banking sector's ability to impact monetary policy.

Muddying the category further, banks have also diversified their financial services so much that these entities no longer resemble commercial banks. In the United States many banks can trade, underwrite, and deal in government and municipal securities within their securities dealer unit, which can trade and make markets in several kinds of money market instruments, including Federal funds, banker's acceptances, commercial paper and certificates of deposit. Large banks, in particular, provide a wide range of financial services. Moreover, insofar as banks conduct their traditional credit intermediation, they do so relying on the secondary market institutions created by the originate-to-distribute model, a system that looks more like a dealer market than the traditional bank relationship market.

Annual Report (1982), accessed 1 June 2016 at https:/www.minneapolisfed.org/ publications/annual-reports/ar/annual-report-1982-complete-text.

8 I explored this issue in 'So Now Who's Special?: Business Model Shifts Among Firms that Borrow to Lend', 4 J. Bus. \& Tech. L. 261 (2009).

9 Tobias Adrian and Adam B. Ashcraft, Shadow Banking Regulation, (Fed. Res. Bank of N.Y., Staff Report No. 559, 2012), accessed 1 June 2016 at https:// www.newyorkfed.org/medialibrary/media/research/staff_reports/sr559.pdf. 
Also, banks vary in terms of their deposit base - this book's defining feature of bankness. The banks that most closely hew to the depository model of maturity transformation are small community banks that rely primarily on the deposits of customers rather than on funds borrowed from other professional lenders. ${ }^{10}$ Though more numerous than their brethren, community banks present fewer risks to the financial system than large banking organizations. ${ }^{11}$ The larger the bank, the less important deposits become relative to other sources of financing. Domestic deposits may provide 85 per cent of a small bank's funding, but that figure may drop to less than 50 per cent for large banks that borrow from institutional investors in relatively unregulated markets.

Here banks borrow from other professional lenders through large denomination certificates of deposit, secured borrowing and other forms of privately-negotiated debt. Though named banks, these large entities do less of the maturity intermediation that has long defined the depository model. Nevertheless, the funding dynamics of these large banks deserve special attention, especially those that form part of diversified financial combines that also operate investment banks, insurance activities and asset managers.

However, the structure of these financial conglomerates can make it difficult to identify the precise perimeter of a bank. As a result, the conglomerate's managers oscillate between two views of the enterprise. They see the conglomerate as a unified entity, with a consolidated balance sheet, a distinctive market identity, and a comprehensive bundle of compliance duties. (Its clients also see the conglomerate this way. ${ }^{12}$ ) This view folds the depository bank into the larger enterprise. At the same time, managers

10 Some basic statistics about the U.S. banking system suggest a market structure with numerous small banks and a much smaller number of large banks in which deposits (and risk) are concentrated. As of 30 September 2015, the U.S. has approximately 6,200 federally-insured banks, of which roughly 4,500 are state chartered, 1,000 hold national charters, and most of the rest of which are savings institutions. These banks hold about $\$ 10$ trillion in insured deposits, over $80 \%$ of which is held by fewer than 120 banks with the remaining $20 \%$ distributed among 6,000 other banks. Banks in New York state hold about $12 \%$ of these deposits and those in California hold over 10\%. Statistics taken from the Federal Deposit Insurance Corporation.

11 In the U.S., entities subject to the jurisdiction of bank regulators include national banks, state banks, most U.S. bank holding companies (except small ones), and savings and loan holding companies (SLHCs), including any of these entities that are subsidiaries of foreign banks.

12 Even when laws prohibit banks from tying the provision of one financial service with another, clients can demand tying, e.g., conditioning a deal with an entity on the issuance of credit by that entity's affiliate bank. 
also see the enterprise as an aggregate of separate entities with discrete profit, risk and compliance dynamics. In the aggregate view, the bank is a node of compliance costs, reporting burdens and financing dynamics that require a specialized investment of enterprise resources.

Conglomerates can undermine attempts to draw the precise perimeter of the bank and to target it with regulatory standards. Fuzzy organizational boundaries can occur in any industry, but tracing funds flow through large financial combines is especially difficult. Pools of capital animated by animal spirits, banks are agile and fluid, self-structuring insofar as permitted by regulation. Even embedded managers may not be able to grasp the whole. A conglomerate may have a reporting company whose shares are registered, publicly-traded, and subject to disclosure rules, but this is just one of the heads of the hydra. The locus of agency may operate elsewhere or it may even have more than one center. Not surprisingly, senior managers can be surprised by rogue traders or inexplicable financial losses.

Returning to Mr. Corrigan's question - given that banks engage in non-bank activities, do not consistently rely on retail deposits, hold ever smaller shares of financial assets, and can be absorbed into financial conglomerates does bank remain a relevant category in contemporary financial markets? This book offers a resounding 'yes'. In spite of any limitations, the term bank - especially its connotations to deposits, maturity transformation and the borrow-short/lend-long model - remains a conceptual benchmark for understanding financial institutions, even as disintermediation and the originate-to-distribute model have created a credit market populated with non-bank firms. ${ }^{13}$ The depository bank is the protagonist of this story with shadow banks playing important supporting roles.

First, when regulating new entities or non-bank financial institutions, regulators use the bank as their reference point. In part, the depository model still serves as a liquidity laboratory in which to observe the impact of market innovation on the financial sector. For example, bank deposit insurance and reserve requirements eliminated the risk of deposit runs, but runs on non-deposit liabilities raise similar issues usefully refracted through the historic experience with bank deposits. ${ }^{14}$

Second, the crisis and the ensuing financial rescues by governments and central banks resulted in a reabsorption into the banking sector of assets

13 Disintermediation is itself a bank-centric idea that means the movement of assets and liabilities out of banks and into other firms, instruments, or markets.

14 One example is the Banque de France's September 2015 conference considering the application of bank-style capital rules to insurance companies and other non-bank intermediaries. 
and liabilities that had moved centrifugally out into non-bank financial entities, such as dealer banks and special-purpose vehicles, in the shadow banking sector. As part of this process, banking regulators - and their brethren, central banks - have become even more dominant within the regulatory community. This process of absorption has, at the same time, changed the business of banking by validating its diversification into markets and products formerly relegated to non-bank intermediaries.

Third, a bank casts a compliance aura that extends throughout its host conglomerate. The United States utilizes a dual banking system in which a bank can operate under either a national or a state charter. A company that owns a bank becomes a bank holding company and, as such, falls prey to a host of federal requirements, including registration with the Federal Reserve. ${ }^{15}$ Most large bank holding companies also register as financial holding companies, a regulatory status created in 1999 that lets the holding company engage in a broader range of non-bank financial activities, such as insurance, merchant banking and securities underwriting. ${ }^{16}$ Introduced in 1956 to regulate the market structure of banking, the bank holding company framework had seemed to be waning in the years leading up to the crisis because deregulation had allowed financial conglomerates increasing flexibility in terms of organizing their business activities. As noted later, post-crisis reforms have made the holding company framework relevant again.

These conglomerates operate as bank holding companies and financial holding companies with separately-capitalized subsidiaries conducting different businesses that are functionally regulated by activity regulators. ${ }^{17}$ A Federal Reserve report on the structure of bank holding companies

15 For an excellent analysis of the changing regulatory role played by the bank holding company, see Saule Omarova and Margaret Tahyar, 'That Which We Call a Bank: Revisiting the History of Bank Holding Company Regulation in the United States', 31 Rev. Banking \& Fin. L. 113 (2011).

16 Alternatively, a financial conglomerate which could conduct depository banking in a single entity can conduct a range of other financial services, such as dealer banking, insurance, and asset management.

17 Within the OECD, these are often called financial groups. Stephen Lumpkin, 'Risks in Financial Group Structures', 2010/2 OECD J. Fin. Market Trends 105 (2011), accessed 1 June 2016 at http://www.oecd-ilibrary.org/finance-andinvestment/risks-in-financial-group-structures_fmt-2010-5 kggc0z2fog0. In the United States, other meta-organizational entities have also existed - for example the investment bank holding company - but they have never been as important as the bank and financial holding company regulatory envelopes. For an engaging history of financial conglomerates in the United States, see Robert E. Wright and Richard Sylla, Genealogy of American Finance (Columbia University Press, 2015). 
found that the largest of these entities could have more than 3,000 separate subsidiaries. ${ }^{18}$ For example, Goldman Sachs, JPMorgan Chase, and Bank of America Group are bank holding companies that each own depository and dealer banks. These holding companies are subject to oversight by several United States regulators, including the Federal Reserve, the Federal Deposit Insurance Corporation and state banking regulators. For example, the United States Securities and Exchange Commission regulates broker-dealers, whose business lines tend to revolve around securities markets. Broker-dealers are also active in credit markets. State authorities regulate insurance businesses. Deutsche Bank, UBS, and HSBC are, respectively, German, Swiss, and British financial conglomerates that operate both depository and investment banks as well as other financial businesses. Deutsche Bank, UBS, and HSBC are regulated by their respective national authorities as well as the European Banking Authority and the European Central Bank.

The extent to which a financial conglomerate conducts banking activities also varies between conglomerates. A 2012 report comparing JPMorgan and Goldman Sachs found major differences in how they arrange their business lines. Like bank holding companies generally, each controls many domestic subsidiaries (J.P. Morgan 3,391 and Goldman 3,115). ${ }^{19}$ However, JPMorgan's four commercial bank subsidiaries held 86 per cent of its consolidated assets, while Goldman's domestic commercial bank assets accounted for less than 12 per cent of its consolidated assets. This represents Goldman's corporate identity as a trading firm, longer on proprietary activity than on traditional credit. So it would seem that JPMorgan dedicates more of its resources to the traditional intermediation function served by depository institutions, suggesting that it has more bankness than some of its competitors.

\section{A FUNDING PERSPECTIVE}

The individual confronts funding when balancing a checkbook or making arrangements to pay utility bills. Essentially the same dynamics play out on a larger and more complex scale for financial intermediaries. Mine is a funding 'relevancy' argument that points in the opposite direction of the

18 See Dafna Avraham, Patricia Selvaggi and James Vickery, 'A Structural View of Bank Holding Companies', 18 FRBNY Econ. Policy Rev. 65 (July 2012).

$19 I d$. For regulatory purposes, the minimum threshold of parent ownership of the subsidiary's voting shares is only $25 \%$, less than the $50 \%$ used for financial accounting. 
capital irrelevancy theorem made famous by Modigliani and Miller. As a result, this argument draws on the theoretical grounding of those like Hyman Minsky, who emphasized the importance of liability structure, especially that of financial intermediaries like banks. ${ }^{20}$ Consequently, in corporate finance how financial intermediaries finance themselves forms a genus because these firms share a nucleus of dynamics alien to non-financial businesses. Within this genus, how banks finance themselves constitutes a species, one especially worthy of study because banks contend with both open market capital requirements and regulatory standards imposed by governments. Deposits are the bank's signature funding source, but bank finance involves a more complex set of dynamics. Because financial intangibles - cash and credit - are its stock in trade, the bank mutates easily, responding to changes in borrower demand and supply-side changes in money markets. Looking at funding practices reveals these dynamics. ${ }^{21}$

Consequently, a funding perspective focuses on the right side of the bank's balance sheet, including both its liability structure and its equity capital. Banks create and sustain an intentional mismatch between their assets and liabilities. Typically, banks use demand deposits and short-term borrowed money to fund mortgages and other long-term investments. This funding strategy - the borrow-short/lend-long model - has long been

20 See José Gabilondo, 'Leveraged Liquidity: Bear Raids and Junk Loans in the New Credit Market', 34 J. Corp. L. 447 (2009). Minsky shows that the liability structure of these entities tended toward financial crises. Specifically, he developed a technical definition of Ponzi finance to classify liabilities based on their tendency to contribute to a firm's financial fragility, which, in the aggregate, would lead to financial stability in an entire sector.

21 This book focuses on the funding structure of banks, but the right side of the balance sheet is a prism for non-bank financial intermediaries too, a theme developed by Chapter 3. Because broker-dealers hold securities both as principal and as agent for other investors, broker-dealers hold large portfolios of securities. To reduce their carrying cost, dealer banks finance these securities by using them as collateral for short-term loans, often overnight. An insurance company makes a long-term promise to its policyholders through its policyholders' account, an aggregate liability that consolidates its duties to policyholders. The opposite of the bank, the insurer has long-term liabilities funded by premium flows and its investment portfolio. Underwriting losses may create funding pressure, but here the direction of the asset-liability mismatch buys the insurer time to adjust to its pending promises. Special-purpose vehicles divide cash flow from a pool of segregated assets between different certificated interests, whose terms determine how much cash the money position needs. The special-purpose vehicle tries to manage its receivables so as to honor the payment promises embedded in the mortgagebacked securities that it issues. 
the depository bank's trademark profit strategy. However, it leaves banks permanently at risk that a shortfall in their current assets will threaten their ability to honor a maturing payment. Before deposit insurance, fractional reserve banking amplified this risk because the bank could serially leverage customer deposits into an exponentially larger portfolio of investments. ${ }^{22}$

A feature that amplifies the bank's vulnerability to financial instability is its willingness to enter into contracts that bind the bank to disburse funds at the election of the customer or after the occurrence of an event beyond the bank's control. The bank must take account of the funding implications of these contingent contracts. So, assets should take account of the potential asset growth in the event that a customer draws down on one of these contingent credit promises. Similarly, the bank must factor in that such a drawdown may require borrowing funds in order to keep its promise to the customer.

In addition to borrowing money, banks fund themselves with equity raised from owners. ${ }^{23}$ Owners cannot demand a payout from the bank, hence their capital is locked in for an indefinite interval and serves as a more permanent form of financing than liability funding. Owners can sell their shares, but this does not deplete the bank's shares. When a bank's assets suffer a loss, the bank's equity absorbs this loss by being reduced dollar-for-dollar. Equity capital reassures lenders, who see the common stock and retained earnings as a financial buffer against loss. Owners get their contribution back - if at all - only after the bank honors the claims of creditors. Hence, a bank's net worth (its equity) is a proxy for its ability to absorb losses. ${ }^{24}$ Also, the federal government stands ready to back stop a bank's insured depository liabilities, effectively increasing the bank's capacity to absorb losses. ${ }^{25}$

For banks, maintaining the capacity to bear loss is crucial. Not only do

22 An excellent resource for better understanding fractional reserve banking in detail is Modern Money Mechanics (Fed. Res. Bank of Chicago, 2011).

23 Creditors of non-bank firms rely primarily on private law - especially contract - to protect themselves from the risks of a firm's illiquidity.

24 Sometimes the equity adjusts in response to a write-off of an asset. A bank's equity can also absorb losses - typically unrelated to ordinary operations through adjustments to a bank's other comprehensive income.

25 Unlike other private firms, banks must comply not only with the open market capital standards imposed by its creditors and owners on all firms but also with a panoply of government requirements designed to shore up bank funding. Governments impose these requirements in response to the bank's labile money position and the risk that the public treasury will have to indemnify the insured depositors of bank that becomes insolvent. 
creditors and owners care, but - exposed as insurer of customer deposits the federal government favors a deep capital cushion so as to mitigate the need for it to have an important stake in the bank's loss-bearing capacity. To that end, federal regulation imposes complex requirements on the structure of a bank's equity capital, a theme examined in Chapter $5 .{ }^{26}$

Changes in bank funding dynamics often trigger inflection points in banking supervision history, which seems to obey a recursive cycle of banking crisis, followed by rescue and financial reform, followed by movements to roll back regulation, which can often trigger another crisis, restarting the cycle. Consider the funding problems of U.S. savings and loans institutions in the 1980s. Trapped by rising market interest rates that increased their funding costs, state usury laws that limited how much the savings and loans could charge borrowers, competition from non-bank lenders, and federal restraints on the interest that could be paid to attract retail deposits (a stable funding source), these depository institutions ended up with troubled balance sheets. In the early 1980s, Congress responded by deregulating savings and loans, which would now be allowed to offer variable-rate products and pay more for their deposit funding. While these new powers allowed savings and loans to grow, they did not, unfortunately, make the institutions more stable. As a result, in 1989 Congress ended up authorizing a large-scale workout of the industry through the Resolution Trust Company. ${ }^{27}$

Contrast a funding analysis of the 2007 crisis with one that emphasizes asset class. An asset class view explains the crisis by focusing on the creation of families of high-risk assets, plotting how their market value changed over time, and evaluating how price discovery worked or failed for these assets. From this perspective, the atom was the primary market

26 Prudential regulators focus on two related measures of a bank's ability to bear losses: (i) the amount and quality of its equity capital; and (ii) its overall leverage. To police capital sufficiency against these measures, regulators require banks to prepare modified financial reports - the regulatory balance sheet - that depart from generally accepted accounting procedure in several important ways. Some adjustments impact how assets are valued and how the bank sets aside reserves for expected losses. Other adjustments - more complex and variable - address the problem of unexpected losses. These funding requirements establish objective limits on the structure of the bank's equity capital.

27 See generally Lee Davison, 'Politics and Policy: The Creation of the Resolution Trust Corporation', 17 FDIC Banking Rev. 17 (2005); 'The Savings and Loan Crisis The Savings and Loan Crisis and Its Relationship to Banking to Banking', in History of the Eighties - Lessons for the Future, Volume 1, ch. 4, Federal Deposit Insurance Corporation, accessed 1 June 2016 at https://www.fdic. gov/bank/historical/history/167_188.pdf. 
credit issued to borrowers of dubious repayment ability. In the residential context, this meant subprime mortgages - many with resettable, variable interest rates - issued under relaxed underwriting standards. In the corporate context, this meant covenant-lite loans in which lenders had waived their traditional creditor protections. What Michael Milken would have more bluntly called a junk loan became leveraged finance, typically credit that was floating rate, subordinated, and below investment-grade. ${ }^{28}$

In the secondary market, promoters funneled these subprime credits through special-purpose vehicles to produce asset-backed securities (including mortgage-backed securities and collateralized loan securities), some of which were investment-grade. Promoters then funneled these asset-backed securities through special-purpose vehicles that issued collateralized debt and loan obligations, including the super-senior investmentgrade tranches that many banks held. When subprime borrowers began to default on the underlying obligations - the ones issued in the primary market - prices in the secondary market for first- and second-generation asset-backed securities waivered and then tanked. The asset class view emphasizes the pricing anomalies of these families of high-risk asset classes - subprime residential credit, other forms of leveraged finance and asset-backed securities (ABS). Valuation is a core problem because it seems that price discovery did not work.

The asset class view tells an important part of the story. However, a funding perspective emphasizes the way that financial links developed between borrowers, lenders, institutional investors, securitization promoters and secondary markets. In the years leading up to the crisis, these financial links resulted in a virtuous funding spiral that made it easy for each of these constituencies to borrow or lend. When the market turned, the same links produced a vicious funding spiral during which borrowers, lenders and investors struggled to refinance or exit their financial positions. To understand the expansionary and deflationary phase of these liquidity cycles, a funding perspective emphasizes two opposite poles of the bank's financial structure: the ultra-liquid assets (booked in the top left side of the balance sheet); and the most residual level of equity (booked in the lower right corner of the balance sheet). The former addresses the firm's funding liquidity, that is, the firm's daily and

28 Since his release from federal prison for fraud in connection with junk bond financing, Mr. Milken has established the Milken Institute, which provides financial and policy analysis about emerging risk products. See, e.g., Glenn Yago and Donald McCarthy, The U.S. Leveraged Loan Market: A Primer, (Milken Inst. 2004), accessed 1 June 2016 at http://assets1c.milkeninstitute.org/assets/ Publication/ResearchReport/PDF/loan_primer_1004.pdf. 
permanent need to profitably refinance maturing obligations (including contingent liabilities) and to fund new assets (including draw-downs on contingent credit facilities). The latter refers to the firm's ability to absorb unexpected losses should they occur. Of course, particular assets matter, but a funding perspective explains the role that these asset classes play in funding liquidity and loss-absorption. A bank funding account focuses on the bank's idiosyncratic liquidity and loss features and its role in funding other entities.

Consider such a funding account of the crisis. Leading up to 2007, several factors left banks wondering whether the ordinary trade-offs and risks of borrowing and lending simply did not apply. First, beginning in 2001, the Federal Reserve kept interest rates relatively low, leading to cheap money that encouraged individuals and firms to ramp up their leverage. Second, securitization amplified the leverage cycle by creating new incentives for lenders, borrowers and investors in the secondary market. Securitization made it easier for lenders to convert outstanding mortgages and other long-term receivables into liquidity reserves that needed reinvestment into new credits. Third, these changes made the bank's shortterm liquidity position more volatile, but the bank had more options for managing this risk.

In effect, a value chain had emerged that connected the bank's internal liquidity with trading conditions in secondary markets for securitized credit. A value chain is a systematic way of mapping how a firm produces value through a sequential production process that involves upstream suppliers and downstream clients. ${ }^{29}$ It is a useful way to understand the dealer market because securitization typically involves several parties linked contractually rather than by membership in a conglomerate. ${ }^{30}$ This liquidity value chain made it easier for banks to finance their activities and, this way, monetize liquidity advantages into the bank's profit margin, but it came with new risks. This liquidity chain - in particular, its development, its capacity to create funding spirals and its volatility - was the catalyst for the ensuing financial crisis.

29 Michael Porter, Competitive Advantage: Creating and Sustaining Superior Performance (Free Press, 1998), 33-61.

30 Porter uses value chain analysis to disaggregate a company into its constituent 'activities' and then separately to trace how that activity contributes to creating customer value. $I d$. Applying the metaphor to a bank requires substituting financial commodities and operations for the activities associated with manufacturing and service industries. My argument traces the upstream and downstream implications of liquidity as a discrete financial commodity, but the value chain may help to disaggregate the financial firm more broadly. 
When the market turned in 2007 and hit bottom in 2008, the mechanisms that had kept the funding spiral working began to move in reverse, creating a liquidity risk chain that made it hard even for investmentgrade borrowers to fund themselves. An early warning sign came when some European structured investment vehicles marketed by Bear Stearns (Bear) faced cash shortfalls due to loan defaults. Bear gave them financial asylum by taking them back onto the consolidated balance sheet. Soon, however, Bear would face its own refinancing problems at the enterprise level. As rumors about Bear's stability spread, its secured lenders refused to roll over maturing loans, precipitating the problem. In March 2008, Bear went cap in hand to the Federal Reserve (Fed), which - after some handwringing - arranged refinancing terms that it made it possible for JP Morgan to acquire Bear. The Fed also provided refinancing for AIG, which became swamped with liabilities when the market turned against the firm's short position in credit default swaps, a kind of financial insurance that shifts default risk from a third-party borrower on to AIG.

During the lead up to the crisis, bank funding practices had changed. Like other firms before the crisis, banks had taken advantage of the new ways to release liquidity trapped in long-term assets. As secondary market investors waited for new ABS products, banks faced competition from non-bank originators. Banks cut margins to compete and provided credit and liquidity support to non-bank originators, who would borrow from the bank to fund their origination. Banks had become dependent on secondary markets to convert long-term receivables into liquid resources. When skittish investors withdrew secondary markets and as wholesale lenders refused to roll over maturing debt, banks faced a liquidity crisis. Making matters worse, at the same time banks also faced a deluge of drawdowns on credit lines by non-bank firms. Surprisingly, assets viewed as good collateral were also viewed as risky, making it harder for the bank to use its assets as security for a loan. As assets declined in value, hundreds of banks failed.

The crisis resisted the initial stabilizing efforts of governments and central banks, including lowering the interest rate or providing conventional lender of last resort liquidity. These trials and tribulations cast doubt on some of regulators' presuppositions about the credit markets. The situation called for something different. The turning point came when central banks grasped the need to replicate a virtuous funding cycle, albeit a synthetic one. Banks had become so invested in structured finance and so dependent on secondary markets that only systemic lending to the liquidity chain as a whole would help. Fighting fire with fire, the Fed set up its own shadow banks to bail out Bear, AIG, and their 
counterparties. ${ }^{31}$ Learning by doing (and, in the case of Lehman, not doing), the authorities began to figure it out. By offering last resort credit to a wider set of borrowers and accepting structured finance as collateral, the Fed and other central banks jumpstarted the money market and gave banks, non-banks and other borrowers a new lease on managing their short-term liquidity. In effect, the Fed was trying to jumpstart the virtuous funding spiral. Along the way, the central bank reintermediated large swathes of the financial market back into the banking sector.

The crisis and the financial rescue raised a battery of questions about public policy. What had worked in practice would now have to be made to work in theory. How was it that secondary markets - financing engines before the crisis - suddenly locked up so suddenly and completely? How had non-bank originators and traders of credit come to play such a significant role in the credit market? Why had banks done such a poor job at forecasting the liquidity that they would need when customers drew down on committed credit lines? Why did the financial insurance promised by credit default swaps prove to be illusory? Why had bank equity reserves not seemed sufficient to signal solvency to investors? How would banks intermediate in a new credit market populated with non-bank competitors and subject to powerful and volatile funding spirals?

Some of these questions reprised long-standing and, perhaps, intractable concerns about the credit market, for example, the perennial challenges of overleveraging by banks, but the seriousness of the financial disruption and the ensuing recessions in the real economy created a sense of urgency. This would lead to an explosion of papers, laws, regulations, policy positions and business practices working out the implications of the new funding market dynamics.

Writing in 2008, a consortium of financial regulators published two sequential reports that presaged the conceptual shift that was taking place in the minds of regulators, bankers and policy officials at multilateral institutions. ${ }^{32}$ The reports emphasized the funding dynamics at work in

31 I describe these initiatives in financial and legal detail in 'Financial Hospitals: Defending the Fed's Role as a Market Maker of Last Resort', 36 Seattle Univ. L. Rev., 731 (2013).

32 Senior Supervisors Group, Observations on Risk Management during the Recent Market Turbulence (2008), accessed 1 June 2016 at https://www. sec.gov/news/press/2008/report030608.pdf [hereinafter Observations on Risk Management]: Senior Supervisors Group, Risk Management Lessons from the Global Banking Crisis of 2008 (2009), accessed 1 June 2016 at https://www.sec. gov/news/press/2009/report102109.pdf [hereinafter Risk Management Lessons]. The Senior Supervisors Group included representatives from Canada, France, Germany, Japan, Switzerland, the United Kingdom, and the United States. 
the crisis. In particular, business models that funded long-term illiquid assets using short-term funds proved the most susceptible to disruption. This was troubling because depository banks had long used a borrowshort/lend-long strategy to intermediate credit and liquidity on behalf of customers. The problem was that banks and other market participants had not reckoned with the basic risks posed by their business models. ${ }^{33}$

By pointing to funding dynamics, these reports took an important step towards resolving the conceptual crisis that persisted after the financial crisis ended. Thematizing these dynamics gave rise to a nucleus of ideas linking secondary market conditions, the bank's short-term financial position, its leverage, its capital adequacy, its business model, and the role of regulation. First, a unitary notion of liquidity gave way to two complementary notions about separate links in the value chain: the asset liquidity of markets and the funding liquidity of firms, including banks. ${ }^{34}$ Within funding liquidity, its short-term dynamics emerged as a priority, in particular those relating to contingent liabilities, funds from wholesale lenders, and secured finance.

As part of this conceptual elaboration of liquidity, its relationship to leverage became more central. The Fed and its associated economists published several important papers that would serve as anchors of the new paradigm. ${ }^{35}$ These papers helped to map the leverage and liquidity dynamics of different types of financial intermediaries leading up to the crisis and, importantly, to conceptualize how shadow banks performed intermediation. In particular, Governor Daniel Tarullo of the Fed has consistently emphasized the priority of liability structure when devising capital regulation for both banks and nonbank intermediaries. ${ }^{36}$ Research

33 Risk Management Lessons, supra note 31, at 15-16.

34 An excellent primer on the subject is Roberto Ruozi and Pierpaolo Ferrari, Liquidity Risk Management in Banks Economic and Regulatory Issues (Springer, 2013). See also Ryan N. Banerjee and Hitoshi Mio, The Impact of Liquidity Regulation on Banks (Bank for Int'l Settlements, Working Paper No. 470, 2014) (how banks adjust balance sheets in response to liquidity regulation): Christoph Memmel and Andre Schertler, 'The Dependency of the Bank's Assets and Liabilities: Evidence from Germany', 18 European Fin. Mgmt. 602 (2012) (how term and liquidity transformation impact earnings).

35 Tobias Adrian and Hyun Song Shin, Liquidity and Leverage (Fed. Res. Bank of N.Y., Staff Report No. 328, 2010), accessed 1 June 2016 https://www. newyorkfed.org/medialibrary/media/research/staff_reports/sr328.pdf: Adrian \& Ashcraft, supra note 9.

36 In the Federal Reserve, Governor Daniel Tarullo has emerged as a forceful advocate of this view. Governor Daniel K. Tarullo, 'Capital Regulation Across Financial Intermediaries', Speech at the Banque de France Conference: Financial Regulation-Stability Versus Unifomity: A Focus on Non-Bank Actors 
papers used statistical modeling to analyze the impact on bank balance sheets of regulation and deposit insurance. ${ }^{37}$ Research also began to thematize the notion of funding as an integrative concept for leverage, liquidity, and long-term capital sufficiency. ${ }^{38}$

Second, central banks substantially expanded their liquidity support by providing systemic lending to a variety of non-bank firms. Willem Buiter's influential editorials in the Financial Times outlined and justified the more muscular market maker of last resort function by central banks. Perry Mehrling drew out the theoretical implications of this central bank role and linked it to traditional notions of asset shiftability ${ }^{39}$ Relatedly, collateral markets emerged as a set of related phenomena. The Bank for International Settlements coordinated several studies and papers examining how collateral markets worked and how central banks impacted them. ${ }^{40}$ Complementing this process, the International Monetary Fund also contributed several important policy papers, including one developing the notion of 'velocity' of collateral to explain how rehypothecation could create systemic risks within and across financial sectors. ${ }^{41}$ This would also impact the financing of central banks, which became more leveraged (often by borrowed bank reserves) to fund their stabilization efforts.

Finally, thinking in terms of business models - and in the funding dynamics of these models - became more common than slotting intermediaries into regulatory silos with neat boundaries and separately-capitalized entities functionally regulated by different activities regulators. ${ }^{42}$

(28 September 2015), accessed 1 June 2016 at http://www.federalreserve.gov/ newsevents/speech/tarullo20150928a.htm.

37 Suresh Sundaresan and Zhenyu Wang, Bank Liability Structure (Kelley Sch. of Bus. Research Paper \& Columbia Bus. School Research Paper No. 14-41, 2014), accessed 1 June 2016 at http://papers.ssrn.com/sol3/papers. cfm?abstract_id=2495579.

38 Andrea Cardillo and Andrea Zaghini, 'The Recent Trends in Long-Term Bank Funding', 137 Banca D'Italia Questioni di Economia e Finanza (2012), accessed 1 June 2016 at http://papers.ssrn.com/sol3/papers.cfm?abstract_id=2176242.

39 Perry Mehrling, The New Lombard Street: How the Fed Became the Dealer of Last Resort (Princeton University Press, 2010).

40 Markets Comm., Bank of Int'l Settlements, Central Bank Collateral Frameworks and Practices (2013), accessed 1 June 2016 at http://www.bis.org/ publ/mktc06.pdf.

41 Manmohan Singh, Velocity of Pledged Collateral: Analysis and Implications 9 (Int'1 Monetary Fund, Working Paper WP/11/256, 2011), accessed 1 June 2016 at http://nowandfutures.com/large/VelocityOfPledgedCollateral-wp11256(repo_ hypothecation)(imf).pdf.

42 In this context, a business model can mean different things. When used to compare depository banks, the notion brings out differences in how banks 
A self-contained system built on the state's fiat powers, mapping intermediaries onto regulatory silos (for example, depository bank, dealer bank, insurer) was coherent inside the conceptual system, but the map did not necessarily match the reality of financial markets. As the silo approach waned, banking regulators and multilateral policy institutions such as the International Monetary Fund and the Basel Committee on Banking Supervision (BCBS) published papers thematizing the crisis in terms of alternative business models. ${ }^{43}$ As well, some research took a fresh look at non-bank intermediaries, including the failure dynamics of dealer banks. ${ }^{4}$

The upshot of these developments is an integrated notion of funding that subsumes capital sufficiency and funding liquidity as interdependent aspects of the financial stability of financial intermediaries, especially banks. ${ }^{45}$ Post-crisis statutory reforms bear the unmistakable imprint of this idea. Coming after a long period during which national regulators ceded discretion to banking organizations to rule themselves, these reforms also amount to re-regulation in which governments took back discretion over key areas, like establishing the parameters that banks must follow when conducting stress-tests. The first major financial rescue in the United States - though named after Troubled Assets - focused on the right side of the balance sheet because it recapitalized several large banks with preferred stock. Subsequent statutes would raise regulatory capital

organize their businesses. For example, in the United States Wells Fargo tends to have a more retail focus and Chase tends to have more of a commercial focus. Both are banks but they focus on different businesses. When applied more broadly to financial intermediaries, the notion brings out differences between regulatory silos, e.g., an insurance company versus a bank or a hedge fund. When applied to financial conglomerates, the term refers to how the enterprise balances its resources between banking, insurance, dealer banking, and other activities.

43 Adrian Blundell-Wignall, Paul Atkinson and Caroline Roulet, 'Bank Business Models and the Basel System: Complexity and Interconnectedness' 2013/2 OECD J. Fin. Market Trends 1 (2014), accessed 1 June 2016 at http://www. oecd-ilibrary.org/content/article/fmt-2013-5jzb2rhkd65b; Yener Altunbas, Simone Manganelli and David Marques-Ibanez, Bank Risk During the Financial Crisis: Do Business Models Matter? (European Cent. Bank, Working Paper Series No. 1394, 2011), accessed 1 June 2016 at https://www.ecb.europa.eu/pub/pdf/scpwps/ ecbwp1394.pdf; Leonardo Gambacorta and Adrian van Rixtel, Structural Bank Regulation Initiatives: Approaches and Regulations (Bank for Int'l Settlements, Working Paper No. 412, 2013), accessed 1 June 2016 at http://www.bis.org/publ/ work412.pdf.

44 Darrell Duffie, How Big Banks Fail and What To Do About It (Princeton University Press, 2011). In the U.S., dealer banks register with the U.S. Securities and Exchange Commission as broker-dealers.

45 See Tarullo, supra note 36. 
standards and, crucially, impose new regulatory liquidity standards ${ }^{46}$ This also means subjecting non-bank firms to funding regulation similar to that imposed on banks, including regulatory capital and liquidity. ${ }^{47}$

Since the 2007 crisis, the regulatory landscape for bank funding has become more complex and promises to continue in that direction for the foreseeable future. In the next few years, internationally-active banks will have to comply with a broad range of complicated regulations that impact their funding. In addition to the regulatory capital and liquidity requirements examined in the following chapters, U.S. banks now comply with Comprehensive Capital Analysis and Review programs and will soon have to digest looming requirements about total loss-absorbing capital and Global Systemically Important Banks capital buffers. ${ }^{48}$

\section{THE PLAN OF THIS BOOK}

The book treats bank funding as a unified notion that began to gel during the 2007 financial crisis, continues to do so, and has come to shape post-crisis banking regulation and banking business models in important ways. As elaborated in post-crisis regulatory sources, funding encompasses the bank's short-term liquidity and its loss-absorbing capital

46 As discussed later, Basel III and its implementing legislation directly enhanced funding standards for many countries. After the crisis, lawmakers in the United States also imposed other requirements that reflect the importance of funding, especially through the Dodd-Frank Act, e.g., more non-deposit liabilities now count in a bank's deposit insurance assessment base, several factors related to a firm's liability structure determine whether it poses systemic risks, and limits are imposed on the short-term debt of systemically relevant firms. Though these developments do form part of the wider conceptual upgrading of funding, liquidity, and liability structure, they did not arise directly out of the Basel requirements, hence I do not discuss them in this book.

47 As a result of this designation, General Electric Capital Corporation decided to divest itself of financial enterprises to avoid having to comply with the federal regulation associated with being a systemically important non-bank financial institution.

48 The Federal Reserve has introduced several new reporting forms to track liquidity issues including the Complex Institution Liquidity Monitoring Report ('FR 2052a') and the Liquidity Monitoring Report ('FR 2052b'). Bank holding companies designated as G-SIBs must complete FR 2052a daily. Most other bank holding companies must report under the FR 2052b monthly and quarterly, respectively. Foreign banking organizations with U.S. broker-dealer assets greater than $\$ 100$ billion must submit a shortened FR 2052a twice monthly and at the request of supervisors. 
and will eventually include the bank's mid-term liability structure, the sector between current liquidity and equity. Modestly, this book offers a framework for understanding bank funding as an organic and evolving concept. The book proceeds in three major parts: a comparative approach to understanding the bank funding model; a survey of how the crisis changed the model's conceptual contours; and an analysis of how the model influences post-crisis thinking about funding regulation.

Part I puts the bank funding model in context by presenting the financing challenges facing banks and comparing the bank funding model with some important competitors. Chapter 2 examines the bank's liability structure from the point of view of its intermediation activities. These activities expose the bank to several funding risks, including mismatches in its asset-liability structure and the need to finance large, sudden demands for funds by customers. The bank can manage these risks because it has unrivaled access to a variety of liability markets, including government funds not available to other intermediaries. To provide a comparative perspective, Chapter 3 sketches funding portraits of three non-bank intermediaries: dealer banks; income assurance entities such as insurers and pensions; and passive income vehicles, such as asset managers and securitization conduits. Each funding model reflects its style of intermediation: dealer banks focus on securities and collateral; income assurance entities convert current income streams into long-term liabilities; and passive vehicles segregate financial risk in a variety of ways.

Consisting of Chapter 4, Part II highlights some of the major funding lessons learned from the 2007-2008 crisis. Many of these insights reflected the breakdown of the securitization practices that had reorganized the credit market in the years leading up to the crisis. Retail and corporate borrowers defaulted; investment demand for mortgage-backed securities in secondary markets evaporated; solvent firms with good collateral could not refinance their maturing debt; contingent liabilities swamped the balance sheets of financial intermediaries; investment-grade debt seemed to underperform; and banks failed. Through trial and error, central banks restored financial stability by becoming market makers of last resort, ballooning in size as their balance sheets absorbed unwanted assets and paid for them by growing the monetary base. Dogmatic approaches yielded to pragmatic solutions to the acute period of the crisis during 2008. The crisis and its resolution forced lawmakers, regulators and academics to reassess how they thought about the banking sector. This process has left us conceptually enriched.

This rethinking has also had important consequences for funding regulation, considered in Part III. Chapter 5 examines regulatory capital, the most developed form of pre-crisis funding regulation. In tandem with 
market capital standards, regulatory capital establishes the legal framework for how the bank manages its equity capital. Chapter 6 examines the most significant post-crisis innovation of funding regulation - regulatory liquidity, whose path of liquidity regulation resembles that of regulatory capital. Initially, regulators made subjective judgments about capital adequacy, but, after a process of global collaboration, the objective system of risk-weights and ratios emerged. So too with regulatory liquidity. As a result, banks must now remain in a state of permanent readiness to manage challenging funding spirals. Because these new regulatory standards address the bank's liquidity, the standards go to the heart of the traditional bank business model. I conclude by reprising some of the major insights afforded by my argument. The Appendix provides a short case study of bank funding. 